\title{
Pensadores da libertação: aproximações entre José Martí e José Enrique Rodó
}

Isabella Meucci*

\section{Resumo}

0 cubano José Martí (1853-1895) e o uruguaio José Enrique Rodó (1871-1917) fariam parte de um terceiro momento da história do pensamento latino-americano, denominado por Leopoldo Zea "filosofia da libertação". Diferentemente do primeiro período, dos "românticos", e do segundo, dos positivistas "construtores de uma nova ordem", nesse terceiro momento haveria uma preocupação com a formação de uma consciência coletiva nacionalista e antiimperialista diante do fortalecimento norte-americano. Tanto Rodó quanto Martí foram influentes em seu tempo, mas também o transcenderam ao analisarem nas particularidades latino-americanas as formas de romper com a dominação presente na região. De acordo com essa proposta interpretativa, este artigo buscou comparar as elaborações de ambos os autores, especialmente no tocante à construção de uma identidade latina e de uma oposição aos Estados Unidos. Inicialmente, foram retomados os três momentos propostos por Leopoldo Zea para o pensamento latino-americano, a fim de compreendermos os debates nos quais Martí e Rodó estavam inseridos. Em seguida, analisaram-se as especificidades das trajetórias dos autores em seus países de origem, assim como os contextos específicos de produção e recepção de suas obras. Posteriormente, examinou-se de que maneira a identidade latinoamericana foi construída pelos autores, na defesa de uma América "Nuestra" em oposição a uma América "outra" ou "anglo-saxã". Por fim, comparou-se o tipo de perigo representado pelos Estados Unidos para ambos os autores, assim como as soluções propostas para a libertação do subcontinente.

\section{Palavras-chave}

José Martí. José Enrique Rodó. América Latina. Pensamento latino-americano.

\section{Abstract}

The Cuban Jose Marti (1853-1895) and the Uruguayan José Enrique Rodó (1871-1917) would be part of a third moment in the history of Latin American thought, called by Leopoldo Zea "philosophy of liberation." Unlike the first period, the "romanticists" and the second, the positivists "creators of a new order", in this third moment there would be a concern with the shaping of a nationalist and anti-imperialist collective consciousness, in the face of

* Isabella Meucci é doutoranda em Ciência Política na Universidade Estadual de Campinas (UNICAMP), bolsista da Coordenação de Aperfeiçoamento de Pessoal de Nível Superior (CAPES). E-mail: isameucci@gmail.com. 
the American strengthening. Both Rodó and Martí were influential in their time, but also transcended it by analyzing in Latin American particularities the ways to break with the existing domination in the area. According to this interpretative proposal, this article sought to compare the elaborations of both authors, especially regarding the construction of a Latin identity and an opposition to the United States. Initially, the three moments proposed by Leopoldo Zea for Latin American thought were brought back in order to understand the debates in which Martí and Rodó were inserted. We then analyzed the specificities of the authors' trajectories in their countries of origin, as well as the specific contexts of production and reception of their works. Later, we examined how the Latin American identity was constructed by the authors, in defense of a "Nuestra" America as opposed to an "other" or "Anglo-Saxon" America. Finally, the type of danger represented by the United States was compared in both authors, as well as the proposed solutions for the subcontinent liberation.

\section{Keywords}

José Martí. José Enrique Rodó. Latin America. Latin American Thought.

\section{Introdução}

O filósofo mexicano Leopoldo Zea, ao apresentar sua interpretação da história do pensamento latino-americano, propôs três períodos nos quais esse teria se desenvolvido: o primeiro seria o dos "românticos", que negavam o passado como expressão da dominação ibérica e defendiam uma "emancipação mental" para que fosse alcançada uma independência autêntica; o segundo, dos "construtores de uma nova ordem", que se inspiravam no positivismo e buscavam fazer de seus povos somente cópias de formas estranhas à realidade continental; e o terceiro, chamado "filosofia da libertação", antítese do que predominou durante o século XIX, no qual a preocupação se voltaria para a construção de uma consciência coletiva nacionalista e anti-imperialista, diante do imperialismo norte-americano. Nesse terceiro momento, o pensamento latino-americano teria adquirido consciência de sua realidade em suas múltiplas expressões, ao mesmo tempo em que teria rompido com as diversas formas de dependência que lhe foram impostas (ZEA, 1976, pp.8-9).

Dentre aqueles que fariam parte desse último momento, no qual o pensamento latino-americano se tornava consciente dos equívocos de seus antecessores e priorizava a própria realidade, Zea destaca o cubano José Martí (1853-1895) e o uruguaio José Enrique Rodó (1871-1917), além dos 
mexicanos José Vasconcelos (1882-1959) e Antonio Caso (1883-1946). Rodó e Martí, no entanto, inauguraram esse terceiro momento e influenciaram grande parte da intelectualidade do continente entre o fim do século XIX e início do XX, conseguindo transpor as fronteiras de seus próprios países e alcançando inegável prestígio em vida, além de transcenderam seu tempo e serem alçados à categoria de "pensadores latino-americanos".

Partindo da hipótese lançada por Zea, este artigo buscará comparar como as elaborações de ambos estariam inseridas nesse momento da "filosofia da libertação", especialmente no tocante à construção de uma identidade latino-americana e nas análises sobre os Estados Unidos. Destaca-se que, apesar do amplo reconhecimento da obra de Zea, as hipóteses apresentadas pelo filósofo mexicano ainda são pouco exploradas na literatura brasileira, assim como grande parte do pensamento latino-americano. A partir desse enquadramento teórico-metodológico, visa-se compreender o lugar ocupado por tais autores na história desse pensamento, principalmente a partir das rupturas que ambos propõem em relação às gerações anteriores, mas também a partir das aproximações e distanciamentos entre eles. Essa orientação, no entanto, não exclui as potencialidades de outros ângulos analíticos sobre a constituição das ideias no subcontinente.

Quanto às obras aqui analisadas, foram priorizados os artigos da Conferência Internacional Americana (1889-1890) e o ensaio Nuestra América (1891), de Martí, e o clássico Ariel (1900), de Rodó. Ainda que a produção do escritor cubano seja bastante vasta, incluindo ensaios, cartas, crônicas, discursos, obras ficcionais e poemas, acredita-se que, vistos em conjunto, esses escritos selecionados fornecem tanto as elaborações de Martí sobre a identidade latino-americana quanto aquelas sobre o perigo iminente dos Estados Unidos para a região. O clássico de Rodó também possibilita a compreensão da defesa da latinidade em oposição ao avanço do vizinho do Norte. Embora tais produções tenham seus usos e interpretações já bastante consolidados em análises que versam sobre um ou outro autor, ressalta-se aqui o desenvolvimento de uma comparação entre ambas. ${ }^{1}$

\footnotetext{
${ }^{1}$ Agradeço ao parecerista que atentou para a importante análise feita por Cláudia Wasserman em artigo na revista Diálogos, na qual a autora propôs uma comparação entre Martí e Rodó a fim de traçar o percurso intelectual e historiográfico da questão nacional e identitária na América Latina. Destaca-se contribuição de Wasserman para o estudo da conformação de uma identidade latino-americana a partir da desconfiança em relação aos aportes culturais norte-americanos, a formação de redes intelectuais no período, a questão étnica na América Latina, a noção de História em ambos os autores, o público-alvo dos mesmos e a repercussão de suas obras. Ver: WASSERMAN, Claudia. Percursos intelectuais latino-americanos: "Nuestra América" de José Martí, e “Ariel” de José Enrique Rodó - as condições de produção
} 
Inicialmente, retomaremos os três momentos propostos por Leopoldo Zea para o pensamento latino-americano para compreendermos os debates nos quais Martí e Rodó estão inseridos. Posteriormente, analisaremos as especificidades das trajetórias dos autores em seus países de origem, bem como os contextos específicos de produção e recepção de suas obras. Buscaremos, então, entender de que forma a identidade latino-americana foi construída pelos autores, na defesa de uma América "Nuestra" em oposição a uma América "outra" ou "anglo-saxã". Por fim, iremos comparar o tipo de perigo representado pelos Estados Unidos para ambos os autores, assim como as soluções propostas para a libertação do subcontinente.

\section{Românticos, positivistas e libertadores no pensamento latino- americano}

A primeira metade do século XIX foi marcada pela independência e a consequente formação dos Estados nacionais latino-americanos. Havia, no entanto, vários desafios a serem enfrentados nesse processo: delimitação de fronteiras, conformação de uma estrutura administrativa, organização de instituições para a garantia do controle e da ordem sociais e o impulsionamento do desenvolvimento econômico (PRADO; PELLEGRINO, 2016). De forma geral, os projetos para o enfrentamento de todas essas indefinições foram motivo de disputa ideológica entre o conservadorismo e o liberalismo, sendo esse último predominante na consolidação dos governos e na organização das sociedades da região.

Para Zea (1976), esse momento do pensamento latino-americano teria sido marcado pela emergência do "liberalismo romântico", que buscava uma independência "autêntica" por meio da negação da herança espanhola, entendida como origem de todos os males. Diferentemente do romantismo europeu, no qual o passado era reafirmado como justificativa para a

e o processo de repercussão do pensamento identitário. Diálogos, v.8, n.1, p.51-66, 2004. Posteriormente, Regiane Gouveia também propôs a comparação entre os autores a partir da perspectiva da história social, analisando a construção de uma identidade latino-americana em oposição aos Estados Unidos, além do papel da juventude para ambos os autores em sua dissertação. Ver: GOUVEIA, Regiane Cristina. O Enigma Latino-Americano: construção de identidades e polarizações entre América Latina e Estados Unidos nos escritos de Martí e Rodó. Dissertação de Mestrado (História Social da Cultura) - Departamento de História, Pontifícia Universidade Católica do Rio de Janeiro (PUC-RJ), 2012. Já o presente artigo buscará compreender especialmente a formação de uma identidade latino-americana em oposição aos norte-americanos como forma de emancipação, a partir do lugar ocupado por tais autores na história do pensamento latino-americano proposta por Zea. 
realização do destino nacional, o liberalismo romântico negava o passado colonial, visto como origem das forças que impediam o progresso dos povos hispano-americanos, comprometendo a realização de seu destino. Desse modo, surgiram trabalhos históricos que se dedicaram a compreender a realidade negativa da Hispano-América, como Facundo (1845), do argentino Domingo Faustino Sarmiento (1811-1888), e Investigaciones sobre la influencia social de la Conquista y el sistema colonial de los españoles en Chile (1844), do chileno José Victorino Lastarria (1817-1888). ${ }^{2}$

Emergiu também nesse período a admiração pelo destino da outra América, a do Norte, de herança anglo-saxã, cujo passado não atravancaria a realização de seu destino. Enquanto a situação histórica e cultural da América Latina ainda a aproximaria do retrocesso, os Estados Unidos encarnavam o espírito da modernidade e do liberalismo, aproximando-se do progresso (ZEA, 1976, p.139). O desenvolvimento econômico desse país após o fim da Guerra de Secessão (1861-1865) e a realização de uma política expansionista supostamente corroboravam com análises que propagavam a supremacia da raça anglo-saxã sobre a raça latina.

O confronto entre civilização e barbárie se apresentava como a chave explicativa desse momento, no qual a primeira era representada pela Europa francesa e inglesa e, na América, pelos Estados Unidos, de herança anglo-saxã. A barbárie era identificada com elementos indígenas, negros, mestiços e com o passado espanhol que havia deixado como herança a raça latina. Nesse embate, a educação, a garantia da ordem, a imigração europeia, o branqueamento da população e a dizimação do indígena eram as armas da civilização, utilizadas também no período seguinte.

No final do século XIX e início do século XX, o ideal dos emancipadores parecia ter sido realizado. Houve a intensificação do tão almejado processo de modernização latino-americano, com a consequente urbanização, as inovações da indústria, o encurtamento das distâncias com as ferrovias, a chegada em massa de imigrantes europeus, o crescimento das camadas médias e assalariadas, além da inserção subalterna do subcontinente nas correntes do mercado internacional (Cf. PRADO; PELLEGRINO, 2016).

$\mathrm{Na}$ proposta interpretativa aqui adotada para o entendimento do pensamento latino-americano, o positivismo seria a filosofia dos

\footnotetext{
2 Alguns outros nomes do liberalismo romântico seriam: os argentinos Esteban Echeverria (1805-1851) e Juan Bautista Alberdi (1810-1884), o venezuelano Andrés Bello (1781-1865), o mexicano José Maria Luis Mora (1794-1850), o cubano José Antonio Saco (1797-1879) e o peruano Manuel Gozález Prada (1844-1918). Sarmiento, Lastarria e Gozález Prada representariam, para Zea (1976, p.280), o enlace do romantismo e do positivismo hispano-americanos.
} 
"construtores de uma nova ordem", então apoiada na ciência. O esforço do liberalismo romântico teria encontrado, por seus próprios meios, a resposta que buscava nessa doutrina filosófica capaz de romper com o passado e garantir a mudança da índole e do espírito hispano-americano:

o positivismo se apresentou a eles [hispano-americanos] como a filosofia adequada para impor uma nova ordem mental que substituísse o que foi destruído, colocando fim a uma larga era de violência e anarquia política e social [...] Para os hispanoamericanos o positivismo foi visto como um instrumento para mudar uma determinada realidade (ZEA, 1976, p.78-79).

O filósofo mexicano também afirma que todos os países hispanoamericanos teriam se servido do positivismo de diversas formas e de acordo com os problemas mais urgentes para os quais se buscavam soluções. No México, foi base do porfirismo, governo do general Porfírio Dias (18301915). Na Argentina, também com destacada influência de caráter liberal avançado e socializante, com José Ingenieros (1877-1925) e Juan Justo (18651928). Já em Cuba, alinhado com as ideias de Herbert Spencer (1820-1903), teria destaque com os pensadores da independência.

As mudanças advindas do processo de modernização também acarretaram instabilidades políticas e regimes autoritários, a dependência do capital estrangeiro e problemas sociais comuns a muitos dos países latino-americanos. As respostas para esses problemas foram encontradas em análises positivistas que se pautavam no racismo científico e no evolucionismo social. Para esses autores, a inferioridade da raça latina somada à mestiçagem havia tornado o continente incapaz de incorporar a modernização e alcançar o progresso. Segundo Charles Hale (2009), eram inúmeros os intelectuais ${ }^{3}$ que se diziam diagnosticadores de um continente doente, que adotavam teorias europeias injuriosas ao orgulho nacional e regional: "a autodepreciação alcançou o auge na época do positivismo" (HALE, 2009, p.367).

Os debates sobre a questão racial permaneceram vivos entre os intelectuais latino-americanos ainda nos primeiros anos do século XX.

\footnotetext{
${ }^{3}$ Alguns dos exemplos dessas obras são: El Continente Enfermo (1889), do venezuelano César Zumetta; América Latina: males de origem (1903), do brasileiro Manoel Bonfim; Los negros brujos (1906), do cubano Fernando de Ortiz; Pueblo Enfermo, do boliviano Alcides Arguedas; Nuestra América: ensaio de psicologia social (1911), do argentino Carlos Octavio Bunge (Cf. GOUVEIA, 2012).
} 
Entretanto, a Guerra Hispano-Americana (1898), momento no qual Cuba, Porto Rico e Filipinas se libertaram do domínio espanhol com auxílio norteamericano, produziu algumas modificações relevantes no debate. Conforme afirma Mónica Quijada (1997), a guerra teria acentuado a polaridade entre latinos e anglo-saxões, revelando uma grande capacidade convocatória em defesa da latinidade. Passaram a ocorrer atos públicos nos quais o centro da discussão era a oposição entre Estados Unidos e Espanha, anglo-saxões e latinos. ${ }^{4}$ Nesse cenário, o signo da polêmica entre as duas raças passou a ser invertido, positivando-se a latinidade. Para Maria Helena Capelato (2003), os desdobramentos do ano de 1898 teriam contribuído para a afirmação de uma intelectualidade mais integrada e participante em relação às questões de sua época.

Para uma nova geração, que iniciaria a história contemporânea do pensamento na América Latina, o positivismo passava a representar a filosofia do retrocesso:

Os sonhos dos grandes emancipadores mentais eram apenas isso, sonhos. Uma nova utopia, a utopia da ciência, havia substituído outras utopias não menos inoperantes. Os povos de origem latina, em que pesem todas as declarações e esforços de seus guias, seguiam sendo latinos. Nada havia mudado a velha e discutida herança ibérica [...] As velhas ditaduras teológicas eram substituídas, como no México, por ditaduras que pomposamente se denominavam científicas (ZEA, 1976, p.409).

O enfraquecimento do positivismo dava lugar a uma nova geração que, ainda que não tivesse rompido com a ideia de progresso, passou a ressignificála. Essa intelectualidade teria criado as bases de um novo idealismo sem renunciar às conquistas positivistas, compreendendo a realidade própria da América Latina e relacionando-a com a universalidade da cultura. Para Zea (1976, p.412-413), a ordem estática teria se transformado em liberdade criadora, e a ideia de progresso não era mais limitada, pois sua fonte era agora o homem como criador de toda cultura.

Nesse terceiro momento do pensamento latino-americano, denominado "filosofia da libertação", haveria uma maior consciência da realidade do

\footnotetext{
${ }^{4}$ Um desses atos ocorreu no Teatro Victoria de Buenos Aires, no dia 2 de maio de 1898 . O ato buscava arrecadar fundos para a Espanha e repudiava a intervenção dos Estados Unidos na guerra. Em defesa da latinidade, o ato se iniciou com o hino nacional argentino, seguido da Marselhesa, das Marchas Reais da Itália e da Espanha, o prelúdio de "Las Dolores" e a Marcha de Cádiz (Cf. QUIJADA, 1997).
} 
subcontinente, originando uma espécie de nacionalismo cultural e filosófico. Esse seria o ponto de partida para entender e atuar junto aos demais povos. Ou seja, da consciência de suas múltiplas expressões e diversas formas de dependência impostas, partiria a busca da identidade do homem latinoamericano. A partir da construção dessa identidade seria possível exigir o reconhecimento de sua humanidade e de sua participação na construção de uma história que deveria ser a de todos os homens (ZEA, 1976, p.9). A universalidade surgiria do reconhecimento da América Latina de si mesma e não de sua negação, como havia predominado nos momentos anteriores. Para o filósofo mexicano, José Martí e José Enrique Rodó estariam entre os primeiros representantes desse novo momento do pensamento latinoamericano. Claudia Wasserman também destaca o lugar fundamental dos autores na dissensão do pensamento determinista e positivista no final do século XIX e início do XX, uma "posição de vanguarda crítica ao pensamento dominante" (2004, p. 15).

\section{0 apóstolo da independência cubana}

José Martí nasceu em 1853, em Cuba, na cidade de Havana, quando a Ilha e Porto Rico eram as últimas colônias espanholas na América. Desde muito jovem esteve envolvido na busca da emancipação de seu país, sendo detido aos 16 anos e condenado à prisão, acusado de propaganda independentista. Posteriormente foi deportado para a Espanha, onde trabalhou como professor e estudou Direito, Filosofia e Letras. Viveu ainda no México, na Guatemala, na Venezuela, e fixou-se nos Estados Unidos por 15 anos, graças a sua colaboração para jornais de língua espanhola - no final dos anos 1880, mais de vinte jornais do continente divulgavam os artigos de Martí. Além de sua colaboração jornalística, também publicou vasta obra poética, elaborou inúmeras traduções, foi cônsul do Uruguai, da Argentina e do Paraguai. Na década de 1890 dedicou-se à tarefa revolucionária e, em busca da independência de seu país, fundou o Partido Revolucionário Cubano. Em 1895, morreu em combate lutando contra o domínio espanhol (Cf. CARVALHO, 2003).

A independência de Cuba, tão almejada por Martí, só foi concluída três anos depois de sua morte, com a interferência dos Estados Unidos, em 1898. Tal apoio obrigou a Ilha a aceitar a Emenda Platt, que negava a soberania 
do país e o colocava sob tutela econômica e militar dos Estados Unidos. ${ }^{5}$ Os temores de Martí, escritos em carta ao amigo Gonzalo Quesada, dez anos antes de tal acontecimento, haviam se concretizado:

Sobre nossa terra, Gonzalo, paira outro plano mais tenebroso do que o que até agora conhecíamos e que é a iniquidade de forçar a Ilha, de precipitá-la à guerra, para ter o pretexto de praticar a intervenção e, com o crédito de mediador e de responsável, ficar com ela. Ação mais covarde não há nos anais dos povos livres: nem maldade mais fria. Morrer para dar motivo de que se levante essa gente que nos empurra para a morte em seu próprio benefício? (MARTÍ apud RETAMAR, 1983, p.23).

As expectativas de liberdade e soberania que alimentavam o movimento de independência foram frustradas. Da desilusão com tal desfecho, formou-se uma singular consciência nacionalista, que passou a reivindicar uma terceira guerra emancipatória, desta vez contra os Estados Unidos (AYERBE, 2004, p.25). O nacionalismo revolucionário de Martí foi então retomado e incorporado pelos movimentos posteriores, encontrando eco nos guerrilheiros de Sierra Maestra.

Em 1953, quando Fidel Castro foi preso por assaltar o Quartel Moncada, os juízes lhe questionaram quem seria o autor intelectual de tal empreendimento. Castro respondeu: "É José Martí" (Cf. RETAMAR, 1983). Tal episódio demonstra a força das ideias do apóstolo cubano, que não só perduraram ao longo do tempo como serviram de orientação política para o processo revolucionário desencadeado anos depois de sua morte. A trajetória de Martí e seus escritos, a independência de Cuba e a posterior Revolução de 1959 tornaram-se fatos inseparáveis na história cubana.

Os escritos aqui analisados incluem as crônicas e cartas publicadas no jornal argentino La Nación e no mexicano El Partido Liberal, entre novembro de 1889 e abril 1890, em razão da participação de Martí na Conferência Internacional Americana, ocorrida em Washington. A convite dos Estados Unidos, outras dezessete nações reuniram-se nesse evento com o principal objetivo de união por meio do fortalecimento político e do comércio (DULCI, 2008, p. 20). Os escritos de Martí sobre tal Conferência revelam seu temor e sua desconfiança acerca do "vizinho pujante e ambicioso" (MARTÍ, 2013,

\footnotetext{
${ }^{5}$ A Emenda incluía o direito aos norte-americanos de instalarem bases militares e portos em Cuba, além de concessões territoriais e privilégios econômicos que violavam a soberania política do país. Perdurou por muito tempo, mesmo depois de revogada, em 1934.
} 
p.47). Para o cubano, a aliança entre as demais nações do continente e os Estados Unidos seria desequilibrada e responderia, em grande medida, aos anseios daquele país em se tornar uma potência mundial, como veremos posteriormente.

A experiência do Congresso foi também transformada em versos. Em 1891, Martí publicou o livro de poemas Versos Sencillos, no qual afirma de onde veio a triste inspiração em seu prólogo:

Meus amigos sabem como saíram esses versos do meu coração. Foi naquele inverno de angústia, em que por ignorância, ou por fé fanática, ou por medo, ou por cortesia, reuniu-se em Washington, sob a temível águia, os povos hispano-americanos (MARTÍ, 1992, p.61).

Já no ensaio Nuestra América, também escrito 1891, Martí apresentou temas relacionados aos desafios dos povos hispano-americanos naquele momento. Advertiu sobre a necessidade da união das diferentes nações; enfatizou como a especificidade dessas implicaria a originalidade de suas formas de governo; destacou o papel do índio, do camponês e do negro, subjugados nos processos de independência dessas nações; reafirmou o perigo da força dos Estados Unidos, o gigante, diante da fragilidade de uma América que ainda se via como uma aldeia.

\section{Rodó e 0 arielismo}

José Enrique Rodó nasceu em 1872, no Uruguai, na cidade de Montevidéu. De família abastada, cresceu em um ambiente cultural profícuo devido à proximidade de seu pai com notáveis escritores locais. Diferentemente de Martí, viveu em um país independente desde 1825, mas abalado por muitos conflitos internos ao longo do século XIX. A partir de 1870, no entanto, o Uruguai encontrava-se em um ciclo de modernização possibilitado pela intensificação de sua produção agropecuária (cereais, carnes e lã), a expansão do mercado europeu e investimentos da Inglaterra. A população imigrante, de origem europeia, também havia crescido muito no país (de 200 mil, em 1870, para 1 milhão e 500 mil, em 1900); e as conquistas dos trabalhadores no tocante à legislação trabalhista avançaram, em 1900, em questões que no Brasil só se concretizariam em 1943 com a Consolidação das Leis do Trabalho (CLT). Esse era um momento no qual “a nação estava 
sendo redefinida, recriada, repensada" naquele país (IANNI, 1991, p.9).

Para Antônio Mitre (2003), o conflito entre a tradição e a modernidade se daria no Uruguai, nesse momento, no confronto entre uma mentalidade criolla, de raízes agrárias, e uma consciência cosmopolita emergente graças aos novos contornos do mundo urbano. Foi nesse cenário que Rodó se dedicou ao jornalismo, publicando artigos em periódicos do Uruguai e da Argentina. Também foi professor de Literatura na Universidade de Montevidéu, participou da reorganização do Partido Colorado, ocupou o cargo de deputado por três mandatos e assumiu a direção da Biblioteca Nacional (Cf. GOUVEIA, 2012).

O opúsculo Ariel, ${ }^{6}$ escrito por Rodó em 1900, tem como título o nome de um dos personagens de $A$ Tempestade, peça de Shakespeare escrita no início do século XVII. Rodó seguiu um caminho aberto no final do século XIX pelo poeta nicaraguense Ruben Darío e pelo crítico franco-argentino Paul Groussac, qual seja, a utilização dos personagens de A Tempestade como símbolos para se pensar a América Latina. ${ }^{7}$ Próspero, Ariel e Caliban são os três personagens principais da peça de Shakespeare. Em linhas gerais, Próspero é senhor e conquistador de uma ilha mítica, na qual Ariel e Caliban são seus servos. O primeiro é o espírito alado, gênio dos ares, símbolo do belo e da espiritualidade, enquanto o segundo, anagrama de "canibal", é o escravo grotesco e disforme, ligado à matéria e ao imediato.

$\mathrm{Na}$ chave interpretativa de Rodó, Ariel associa-se ao espiritualismo desinteressado dos latinos, enquanto Caliban ${ }^{8}$ aproxima-se do utilitarismo materialista anglo-saxão. Segundo Hale (2009), o ensaio de 1900 exerceu grande influência sobre os intelectuais latino-americanos, especialmente nas duas primeiras décadas após sua publicação, mantendo até os dias atuais sua importância simbólica. Os "jovens da América", convocados para o renascimento do idealismo, responderam ao chamado de Rodó. Formou-se, assim, uma "geração arielista" nas universidades e na vida

\footnotetext{
${ }^{6}$ Outros dois destacados livros de Rodó são: Motivos de Proteo (1909) e El Mirador de Próspero (1913).

${ }^{7}$ Ainda em 1898, Groussac havia associado os Estados Unidos a Caliban em discurso proferido no Clube Espanhol de Buenos Aires em ato de solidariedade à Espanha após o final da Guerra Hispano-Americana. Darío, em relato sobre o mesmo ato, também mobilizou a comparação dos Estados Unidos a Caliban, intitulando o próprio artigo de O triunfo de Caliban (Cf. RICUPERO, 2016).

${ }^{8}$ Vale ressaltar que Rodó não associa diretamente Caliban aos norte-americanos. Ainda que a quinta parte de Ariel verse sobre o utilitarismo materialista e a democracia dos Estados Unidos, a associação dessas características ao personagem Caliban não ocorre de forma direta.
} 
política em diferentes partes da América Latina, especialmente no Peru e no México. Como defendido também por Bernardo Ricupero, esse período pode ser compreendido como "momento Ariel", no qual "o opúsculo de Rodó, em particular, difunde-se entre a juventude da região, servindo como instrumento de afirmação de uma identidade latino-americana" (2016, p.401).

A empreitada de Rodó também foi seguida por diferentes autores que utilizaram os personagens da peça de Shakespeare e suas características para compreender a realidade latino-americana, gerando análises distintas, com intenções variadas e por vezes conflitantes. Entre os mais destacados exemplos dessas interpretações estão Caliban (1969), do cubano Roberto Fernández Retamar, e O Espelho de Próspero (1988), do historiador norteamericano Richard Morse. Retamar, na tentativa de romper com uma visão colonialista da América Latina em um contexto de descolonização da África e da Ásia, transformou Caliban em símbolo do povo oprimido desse subcontinente, Próspero em seu colonizador, e Ariel no intelectual que precisa escolher com qual dos dois deseja se aliar. Morse, por sua vez, apostou na riqueza cultural das sociedades que se engendraram no sul do continente a partir das raízes ibéricas, em contraste com a civilização do norte de raízes anglo-saxãs, que há séculos impõe seu espelho de forma agressiva ao sul. A Ibero-América de Morse se construiria contra o espelho de Próspero, originando uma outra zona americana, "simbolizada ora pelas virtudes de Ariel, ora pelo poder desconcertante de Caliban" (MONTEIRO, 2009, p.359). ${ }^{9}$ Ainda que o arielismo e sua maneira de compreender o continente tenham envelhecido ao longo do tempo e que os personagens da peça shakespeariana tenham assumido significados diversos, o ensaio

\footnotetext{
${ }^{9}$ No final dos anos 1980, a publicação de O Espelho de Próspero de Richard Morse ganhou especial destaque nas Ciências Sociais brasileiras. Entre as reações e elaborações mais célebres estão as de Simon Schwartzman e de Luiz Werneck Vianna. Schwartzman, de uma perspectiva mais liberal, criticou intensamente a simpatia de Morse pelas características da cultura política da Ibero-América, entrando em franca polêmica com o escritor norte-americano. A esse respeito ver: SCHWARTZMAN, Simon. O espelho de Morse. Novos Estudos Cebrap, n.22, p.185192, out.1988; MORSE, Richard. A miopia de Schwartzman. Novos Estudos Cebrap, n.24, p.166178, jul.1989; SCHWARTZMAN, Simon. O gato de Cortázar. Novos Estudos Cebrap, n.25, p.191203, out. 1989. Werneck, por sua vez, viu na obra de Morse uma contribuição importante para se pensar as especificidades da longa revolução passiva brasileira, ainda que sem participar diretamente da polêmica entre os autores. Ver: VIANNA, Luiz Werneck. Americanistas e iberistas: a polêmica de Oliveira Vianna com Tavares Bastos. Dados, v.34, n.2, p.145-189, 1991; VIANNA, Luiz Werneck. A Revolução Passiva: Iberismo e Americanismo na Formação Brasileira. Rio de Janeiro: Revan, 1997.
} 
de Rodó configurou-se como uma das primeiras recepções de $A$ Tempestade na América, possibilitando suas ressignificações futuras (RICUPERO, 2016).

\section{Nuestra América, continente de Ariel}

O filósofo uruguaio Arturo Ardao afirma que a criação terminológica de uma antítese entre a América Saxã e uma América Latina ${ }^{10}$ seria resultado de situações históricas muito complexas. Dentre as que seriam predominantes nesse processo, destacou o avanço do Norte sobre o Sul do hemisfério Americano, com a anexação do Texas, a invasão e o desmembramento do México, e as interferências na América Central. A latinidade, atribuída a partir de então a essa América, assumiria o seu real sentido através do contraste com a condição anglo-saxã da outra América (ARDAO, 1993, p.15 ). Também para o historiador Leslie Bethell, intelectuais e escritores entre os anos 1850 e 1860 já compreendiam a existência de uma identidade e uma consciência hispano-americana/latino-americana que superava diferenças regionais e que se contrapunha à "outra" América (BETHELL, 2009, p.292).

Como visto anteriormente, nessa oposição, a identidade latina foi compreendida com sinal negativo tanto pela geração dos românticos quanto dos positivistas. A América Latina foi considerada como a parte do continente na qual predominavam o atraso, a enfermidade, a barbárie, a raça inferior. Os Estados Unidos, diante das conquistas territoriais e do desenvolvimento econômico, seriam modelo de progresso, civilização, modernidade e superioridade racial.

Rodó e Martí diferem dessa postura ao compreenderem a identidade latina de maneira positiva. No entanto, como será reforçado posteriormente, as diferenças entre o publicista cubano e o uruguaio aparecem na construção do que seria essa latinidade, bem como nos perigos representados por seu oposto, os Estados Unidos.

O contexto no qual positivaram a latinidade também era distinto, pois Martí escreveu e morreu antes da Guerra Hispano-Americana (1898), evento que impactou em grande medida a produção de Rodó e da intelectualidade latino-americana na defesa das tradições formadoras da

\footnotetext{
${ }^{10}$ Foge aos objetivos deste artigo uma análise da gênese e dos usos do conceito de "América Latina". A esse respeito, recomenda-se: MIGNOLO, Walter. The Idea of Latin America. Oxford: Blackwell, 2005; PHELAN, John. El origen de la idea de Latinoamérica. Cuadernos de Cultura Latinoamericana. 31. México: CCyDEL/UNAM, 1979; ROJAS MIX, Miguel. Los cien nombres de América: eso que descubrió Colón. San José: Editorial de la Universidad de Costa Rica, 1997.
} 
América-Hispânica. Precedendo esse movimento e com uma concepção de latinidade distinta, Martí reforçou a ideia de uma América cujo passado, ainda que doloroso, seria motivo de orgulho (MARTÍ, 1983, p.197). Segundo Zea (1976), Martí veria a grandeza latino-americana nessa realidade, nessa história e nesse passado que não deveriam ser ocultados. Diferenciava-se, assim, do liberalismo romântico, que se empenhava em negar as raízes do subcontinente; e dos positivistas, que depreciavam a raça latina.

Para Zea (1976), Martí também seria um dos primeiros a condenar a geração romântica do século XIX ao defender que a solução de dependência da América Latina não poderia ser solucionada com a cópia de ideias e instituições de outras nações, especialmente as vigentes nos Estados Unidos. Ao contrário, a outra América só seria capaz de nos impor novas formas de dependência. Martí teria compreendido que não seria imitando uma civilização que acabaríamos com nossa suposta barbárie. Somente buscando em sua própria realidade, conhecendo e assumindo o passado, os americanos dessa parte do continente encontrariam sua força emancipatória.

É nesse sentido que, no ensaio Nuestra América, Martí modificou a dicotomia "civilização e barbárie", transformando-a em "falsa erudição e natureza":

É por isso que o livro importado foi vencido, na América, pelo homem natural. Os homens naturais venceram os letrados artificiais. O mestiço autóctone venceu o crioulo exótico. Não há batalha entre civilização e barbárie, mas sim entre a falsa erudição e a natureza (MARTÍ, 1983, p.196).

Nessa inversão, Martí buscava criticar a cópia, compreendida como a "falsa erudição" daqueles que na verdade só buscariam a transposição de modelos alheios - tanto europeus quanto norte-americanos. A natureza humana venceria na América por representar a particularidade, o elemento autóctone. Vale ressaltar que o publicista cubano não era contrário às influências externas, mas sim à simples cópia e transposição dessas em detrimento de todo e qualquer elemento próprio da América Latina: “Enxerte-se em nossas repúblicas o mundo; mas o tronco terá que ser o de nossas repúblicas" (MARTÍ, 1983, p.197).

Dessa maneira, Martí poderia ser identificado com os filósofos da libertação, visto que inaugurou o momento no qual o reconhecimento das particularidades da América Latina tornaria possível sua universalidade. Ou como afirma Eugênio Carvalho (2003): 
Em que pese esse sentimento autóctone americanista, sua concepção da história americana esteve marcada por um profundo universalismo, pela consciência de uma história universal vista como processos diferentes e simultâneos e como resultante da história de todos os povos, pela consciência do papel que os povos americanos poderiam desempenhar no concerto das grandes nações e nos destinos da história mundial (CARVALHO, 2003, p. 152).

Diante de um contexto no qual diversas análises positivistas destacavam a "enfermidade" de um continente mestiço, Martí também se diferenciou ao negar qualquer traço de inferioridade advindo da composição étnica desses povos. Defendeu que não existiam raças e que pecaria contra a humanidade aquele que fomentasse e propagasse o ódio entre essas. A mestiçagem não seria um problema, mas uma especificidade latino-americana que deveria ser valorizada. Nesse sentido, a latinidade de Martí ancorava-se também nos índios, nos negros e nos brancos oprimidos. Era preciso fazer com esses causa comum "para afiançar o sistema oposto aos interesses e hábitos de mando dos opressores" (MARTÍ, 1983, p. 198).

Essa mesma consciência da realidade também permitiu sua revalorização, por parte de Rodó, em seu conhecido ensaio de 1900. Ainda de acordo com Zea (1976), o escritor uruguaio teria compreendido a herança e a cultura da América Latina com o signo positivo, encarnadas no símbolo de Ariel, o espírito. Publicado dois anos após a Guerra Hispano-Americana, o ensaio de Rodó também pode ser visto como reação ao choque produzido pela derrota da Espanha, embora não faça referência direta ao acontecimento (HALE, 2009). Como visto anteriormente, esse evento provocou uma reação na América hispânica, que passou a solidarizar-se com a ex-metrópole, por meio da valorização de traços latinos comuns, em contraste com o “poderoso e temível vizinho anglo-saxão" (RICUPERO, 2016, p.378).

Zea (1976) também afirma que esse seria um momento no qual a latinidade se colocava diante do anglo-saxonismo, predominante até então no pensamento latino-americano em virtude do positivismo. O signo negativo atribuído às características desse continente teria feito com que os positivistas buscassem a destruição da herança latina, transpondo modelos externos para efetuar uma mudança na índole de seus povos. Longe de criar as sonhadas democracias liberais, esses sistemas alheios só levaram a ditaduras e a uma maior dependência.

Rodó seria parte de uma geração que compreendeu as limitações desses 
modelos positivistas, voltando-se então para o conhecimento da própria realidade a fim de modificá-la (ZEA, 1976, p.424). Não se trataria mais de destruir o passado e acabar com sua herança, mas sim de compreender suas potencialidades para a construção do futuro. Era especialmente nessa herança que se encontraria a singularidade da América Latina: "na herança de raça, uma tradição étnica a manter, um vínculo sagrado que nos une às páginas imortais da História, confiando à nossa honra sua continuidade no futuro" (RODÓ, 1991, p.72).

No entanto, essa "herança de raça" latina parece mais um produto dos ideais humanísticos e estéticos da civilização greco-romana e cristã. Dessa forma, ao reafirmar a aproximação da América Latina com os gregos e latinos, Rodó também afastou qualquer preocupação com populações que eram maioria no continente: indígenas, negros e mestiços. Essa postura indica o europeísmo dos primeiros intelectuais latino-americanos (Cf. RICUPERO, 2016). Octavio Ianni (1991) também constata a mesma característica: "Ariel é uma contribuição fundamental para a compreensão do europeísmo que impregna o pensamento e o modo de ser de amplos setores sociais das sociedades latino-americanas" (p.7).

Nesse contexto, a revalorização da identidade latina de Rodó se daria em oposição e em relação a uma outra, a anglo-saxã - o espírito de Ariel em luta contra a supremacia de Caliban, a matéria. O espiritualismo, especificidade da "raça latina", deveria ser preservado por sua superioridade em relação ao materialismo anglo-saxão. Para Zea (1976), Rodó se oporia assim às tentativas positivistas de "incorporar os povos da América Latina no carro do progresso, conduzido pelos Estados Unidos" (p.425).

Assim como em Martí, há em Rodó a crítica da cópia da outra América, que destruiria as particularidades dessa América Latina. Essa defesa positivista de um modelo anglo-saxão foi chamada pelo escritor uruguaio de "nordomania", uma mania pelo norte propagada por muitos intelectuais no período em que escreveu: "Temos nossa nordomania. É preciso opor-lhe os limites assinalados, de comum acordo, pela razão e pelo sentimento" (RODÓ, 1991, p.70).

De acordo com Zea (1976), Rodó não negaria o utilitarismo, característica que tornou possível a grandeza de um povo que agora queria se impor como modelo. Pelo contrário, esse mesmo utilitarismo, colocado a serviço dos fins próprios da América Latina, tornaria possível a consolidação das metas específicas desses povos. Como em Martí, a negação de Rodó estava na imitação, pura e simples: 
(...) não vejo glória no propósito de desnaturalizar o caráter dos povos - seu gênio pessoal - para lhes impor a identificação com um modelo estranho a que sacrifiquem a insubstituível originalidade de seu espírito, nem na crença ingênua de que se possa alguma vez obtê-lo com procedimentos artificiais e improvisados de imitação (RODÓ, 1991, p.71).

A solução para a nordomania, portanto, não residiria na negação de toda e qualquer influência materialista e utilitarista, mas em sua incorporação sem que a América Latina fosse deslatinizada. Ou seja, incorporar o melhor do materialismo anglo-saxão sem deixar o espiritualismo latino. A barbárie, portanto, parecia estar associada ao abandono dessa particularidade da América Latina em favor de uma incorporação irrefletida do utilitarismo anglo-saxão.

\section{Outra América, lugar de Caliban}

Segundo Roberto Fernández Retamar (1983), Martí talvez tenha sido o primeiro a vislumbrar plenamente o perigo que pairava sobre a América Latina, enquanto outros intelectuais hispano-americanos ainda se impressionavam com as conquistas territoriais e o desenvolvimento econômico dos Estados Unidos. Para Carvalho (2003), o exílio de Martí nos Estados Unidos teria permitido que ele adquirisse consciência do papel desempenhado por aquela nação na América e no restante do mundo no final do século XIX. Além disso, sua participação no Congresso Internacional Americano (1889) ${ }^{11}$ também pode ser compreendida como crucial para suas elaborações anti-imperialistas. Nesse Congresso, também conhecido como Primeira Conferência Pan-Americana, os Estados Unidos planejavam a criação de uma "União Americana", visando diminuir a influência da Europa e ampliar as relações comerciais com os demais países do continente. Essa política foi caracterizada como "pan-americanismo" (GOUVEIA, 2012).

A postura de Martí sobre os Estados Unidos se modificou ao longo do tempo, adquirindo um traço cada vez mais negativo à medida que se

${ }^{11}$ Essa foi a primeira das Conferências Internacionais de Estados Americanos, também referidas como Conferências Pan-Americanas. As demais ocorreram na Cidade do México (1901-1902); no Rio de Janeiro (1906); em Buenos Aires (1910); em Santiago do Chile (1923); em Havana (1928); em Montevidéu (1933); em Lima (1938); em Bogotá (1948), quando se formou a Organização dos Estados Americanos (OEA); e em Caracas (1954) (DULCI, 2008). 
aprofundava na observação do caráter dessa sociedade (CARVALHO, 2003, p.193). Nascida do amor à liberdade, teria havido um momento nessa "outra" América, no qual predominou a austeridade da virtude. No entanto, essa herança de seus fundadores estaria sendo abandonada no âmbito das relações com os demais povos do continente. Nas crônicas da Conferência, Martí afirmava que os Estados Unidos passaram a condicionar seu progresso e sua liberdade ao comprometimento da liberdade das demais nações do continente americano.

Para Martí, só seria possível compreender essa dimensão do perigo do pan-americanismo ao se olhar para além dos interesses aparentes da convocação da Conferência. O escritor cubano afirmava que não era contrário à proposta norte-americana, que possuía objetivos nobres: união aduaneira, a criação de uma rede de comunicação eficiente entre os portos americanos, a adoção de uma moeda comum, a uniformidade do sistema de pesos e medidas e a arbitragem de disputas.

No entanto, sob essa superfície, encontravam-se outros interesses. A união aduaneira, por exemplo, inundaria a América Latina de excedentes da produção norte-americana e faria com que as economias locais fossem arruinadas. Além disso, a chegada de capitais estrangeiros também se espalharia por todos os setores das economias nacionais, causando-lhes prejuízos. Martí também indicava, nos escritos da Conferência, alguns fatos do século XIX que demonstrariam as reais intenções dos Estados Unidos em relação à América Latina: incentivo à separação do Panamá da Colômbia, apropriação de boa parte do território mexicano, intervenções na Nicarágua, São Domingos, Haiti e Cuba. Na verdade, os Estados Unidos exigiriam a submissão dos demais países. Por isso, seria imprescindível colocar freios, com o pudor das ideias, nas tentativas de unidade proclamadas pelos norteamericanos (MARTí, 2013, p.49).

Martí também recomendava cautela quanto às propostas de unidade com um país que continuava a desdenhar dos povos de Nuestra América, utilizando para tanto a justificativa de inferioridade racial:

Acreditam na superioridade da "raça anglo-saxã contra a raça latina", acreditam na baixeza da raça negra, que escravizaram ontem e humilham hoje, e da indígena, que exterminam. Acreditam que os povos hispano-americanos são formados, principalmente, de índios e de negros. Enquanto os Estados Unidos não saibam mais de hispano-américa e a respeitem mais (...) podem os Estados Unidos convidar a hispano-américa a 
uma união sincera e útil para a hispano-américa? (MARTÍ, 2013, p.182-183)

Os escritos da Conferência apresentavam uma preocupação premente quanto aos avanços dos Estados Unidos, visto que as posturas dos embaixadores latino-americanos demonstrariam o descompasso existente entre as nações que representavam. Havia desde os que julgavam que os Estados Unidos eram sua própria pátria, pois consideravam que somente por meio deles poderiam conseguir a liberdade e a riqueza, até os que tinham uma "alma americana" e defendiam a união das nações hispanoamericanas (MARTí, 2013, p.32). Martí ressaltava as diferenças entre as duas Américas que impossibilitavam a unidade pretendida pelos defensores do pan-americanismo: a "outra" era composta por "um povo agressivo, de outra composição e de fim", (idem, p.55) a "nossa" era composta por "pessoas cautelosas e decorosas" (idem, p.101). Enquanto a "outra" queria "se colocar sobre o mundo", a "nossa" queria "abrir os braços ao mundo" (idem, p.92). Para combater o perigo dessa "outra" América, era necessária a unidade entre os povos de "nossa" América.

Condizente com essa perspectiva, o ensaio Nuestra América também destacava a diferença de "origens, métodos e interesses entre os dois fatores continentais" (MARTÍ, 1983, p.200). A ideia da unidade latino-americana como um projeto político se apresentava de forma mais delineada: "os povos que não se conhecem devem ter pressa em se conhecer, como aqueles que vão lutar juntos (...) devem se dar as mãos para que sejam um só" (idem, p.194). Comparando algumas dessas nações ao aldeão que crê que o mundo é sua aldeia, Martí afirma: "o que restar de aldeia na América deverá acordar" (idem) para que não seja pisoteada por gigantes com botas de sete léguas. Esse era o dever urgente de Nuestra América: "mostrar-se unida em alma e intenção" (idem, p. 200).

A consciência de uma identidade latina, de passado e destino comuns, parecia tornar possível uma unidade que, nesse momento, seria uma questão de sobrevivência. Diante da força da outra América - gigante em povo, território e dinheiro - as repúblicas latino-americanas seriam muito frágeis isoladamente, do que decorreria a necessidade de se conhecerem e se unirem. Como afirma Zea (1976) sobre o pensamento de Martí, a partir dessa realidade, transformada em grande unidade, é que a América Latina poderia se salvar de novas formas de dominação.

Assim como Martí, Rodó também buscou caracterizar aquilo que 
diferenciava as duas Américas para impedir a dominação do Norte. Para tanto, ressaltou que era preciso reconhecer as qualidades dos Estados Unidos antes de evidenciar seus defeitos: "ainda que não os ame, admiroos" (RODÓ, 1991, p.74). Nessa admiração crítica, destacou a construção do conceito moderno de liberdade, os princípios de organização, a lógica, a ousadia, a demonstração da grandeza e do poder do trabalho, a curiosidade insaciável e a eficácia.

Essa "grandeza titânica" (idem, p.77), no entanto, pautava-se apenas na grandeza material, na realidade imediata, na ação e na força em movimento. Por isso estaria longe de uma conduta racional que cumpria as exigências do espírito e da dignidade intelectual e moral, pois menosprezava qualquer pensamento que prescindisse de finalidade imediata. Os Estados Unidos seriam, então, a "encarnação do verbo utilitário" (p.69), oposta ao espiritualismo característico da América Latina. Portanto, se essa era a representação de Ariel, aquela seria Caliban, ainda que indiretamente.

Rodó, ao caracterizar o utilitarismo dos Estados Unidos, adverte também sobre os perigos desse tipo de dominação na América Latina. No entanto, a questão se delineava mais como um perigo moral, advindo da imitação de um modelo utilitarista em uma sociedade espiritualista:

A poderosa federação vem realizando entre nós uma espécie de conquista moral. A admiração por sua grandeza e força é um sentimento que avança a passos largos no espírito de nossos homens dirigentes e, talvez ainda mais, nos das multidões, que se sentem fascinadas com a impressão da vitória. E de admirá-la, é facílimo passar a imitá-la (RODÓ, 1991, p.69).

Essa imitação teria como consequência a deslatinização que, como visto anteriormente, levaria à perda dos elementos particulares aos povos latinos, especialmente o espiritualismo. Como já exposto, a solução estaria na incorporação do materialismo anglo-saxão sem se afastar do espiritualismo latino. Esse processo seria uma obra do futuro da juventude do continente, guiada por uma "elite do espírito".

Para Rodó, as virtudes do entusiasmo e da esperança seriam naturais à juventude, não sendo necessário ensiná-las, mas sim orientá-las para o melhor desenvolvimento da vida. Era então no espírito da juventude que se encontraria "terreno generoso" para que a semente da palavra oportuna gerasse os "frutos de uma imortal vegetação" (RODÓ, 1991, p.15). Através da orientação moral do espírito, essa juventude poderia aspirar à plenitude 
do ser e não ao individualismo e ao utilitarismo, que mutilam a "integridade natural dos espíritos" (idem, p.27). O papel de guia dessa juventude estaria com Próspero, outro personagem de A Tempestade, aqui retomado como símbolo dessa "elite do espírito". Para Ricupero (2016), há uma defesa de certo aristocratismo como forma de reação ao capitalismo norte-americano, um "aristocratismo do espírito" (p. 403).

Tanto o passado quanto o presente pertenceriam ao braço rude que combate, constrói, nivela; mas o futuro poderia ser o cenário do desenvolvimento das faculdades superiores da alma. Só então a América poderia ser hospitaleira, pensadora, serena, firme e regenerada, símbolo de Ariel triunfante: "Ariel triunfante significa idealidade e ordem na vida, nobre inspiração no pensamento, desinteresse na moral, bom gosto na arte, heroísmo na ação, delicadeza nos costumes" (RODÓ, 1991, p.106).

\section{Considerações finais}

Buscou-se aqui uma aproximação entre Rodó e Martí pautada na ideia de que ambos buscaram romper com situações de dependência da realidade latino-americana, inaugurando o que Leopoldo Zea denominou "filosofia da libertação". Nesse sentido, em que pesem as diferenças de contexto histórico, geográfico e geracional dos autores, procurou-se entender aquelas preocupações que os uniam: a identidade latino-americana compreendida em sinal positivo; a crítica à cópia de modelos estrangeiros que anulavam as particularidades do subcontinente; a importância dessas mesmas particularidades na inserção da América Latina na construção de uma história universal; a caracterização dos Estados Unidos em uma chave de oposição à Nuestra América/Ariel; os perigos representados por essa outra América/Caliban; a busca de soluções que rompessem com a situação em que se encontrava a América Latina, afastando-se daquelas até então propostas pelo liberalismo romântico e pelo positivismo.

Por outro lado, destacaram-se também as divergências entre ambos os autores mesmo diante das questões que os uniam: a identidade latina positivada, mas que para Martí compreenderia negros, índios e brancos oprimidos do continente, enquanto para Rodó associava-se aos valores de uma herança greco-romana; a crítica da cópia que representava a batalha entre natureza e falsa erudição para o escritor cubano, enquanto para o uruguaio seria entre o utilitarismo e o espiritualismo; os perigos do vizinho do Norte, que para Martí eram representados internamente 
pela cópia, mas também externamente pelo perigo da perda da soberania dos países da América Latina, enquanto para Rodó seriam especialmente associados a uma questão moral, fruto da nordomania; por fim, as soluções, que para o cubano estariam na defesa de uma unidade de todos os povos de Nuestra América, enquanto para o uruguaio estavam relacionadas a um direcionamento da juventude pela elite do espírito, capaz de incorporar o utilitarismo sem perder de vista o espiritualismo.

\section{Referências}

ARDA0, Arturo.

(1993) América Latina y la latinidad. México, Universidad Nacional Autónoma de México.

AYERBE, Luís Fernando.

(2004). A Revolução Cubana. São Paulo: Editora UNESP.

BETHELL, Leslie.

(2009). 0 Brasil e a ideia de "América Latina" em perspectiva histórica. Revista Estudos Históricos. Rio de Janeiro, v. 22, n. 44, pp. 289-321.

CAPELATO, Maria Helena.

(2003). A data símbolo de 1898: o impacto da independência de Cuba na Espanha e Hispanoamérica. História, vol.22, n.2, pp.3558.

CARVALH0, Eugênio Rezende de.

(2003). América para a humanidade: 0 americanismo universalista de José Martí. Goiânia, UFG.

DULCI, Tereza Maria Spyer.

(2008). As Conferências Pan-Americanas: identidades, união aduaneira e arbitragem (1889-1928). Dissertação de Mestrado apresentada à Universidade de São Paulo (USP).

GOUVEIA, Regiane Cristina.

(2012). O Enigma Latino-Americano: construção de identidades e polarizações entre América Latina e Estados Unidos nos escritos de Martí e Rodó. Dissertação de Mestrado apresentada à Pontifícia Universidade Católica do Rio de Janeiro (PUC-RJ).
HALE, Charles A.

(2009). As ideias política e sociais na América Latina (1870-1930). In: BETHELL, Leslie (org.). História da América Latina (18701930). São Paulo, EDUSP.

IANNI, Octavio.

(1991). Apresentação. In: RODÓ, José Enrique. Ariel. Campinas, UNICAMP.

MARTÍ, José.

(2013). Nuestra América es una. México, Cien de Iberoamérica.

MARTÍ, José.

(1992). Obras Completas (v.16). Havana, Editorial de Ciencias Socialies.

MARTÍ, José.

(1983). Nossa América. São Paulo: Hucitec.

MIGNOLO, Walter.

(2005). The Idea of Latin America. 0xford, Blackwell.

MITRE, Antônio Fernando.

(2003). o Dilema do Centauro: ensaios de teoria da história e pensamento latino-americanos. Belo Horizonte, UFMG.

MONTEIRO, Pedro Meira.

(2009). A paixão latino-americana: Richard Morse. In: BOTELHO, André; SCHWARCZ, Lilia M. Um enigma chamado Brasil. São Paulo: Companhia das Letras.

MORSE, Richard.

(1998) O espelho de Próspero. São Paulo: Companhia das Letras. 
MORSE, Richard.

(1989). A miopia de Schwartzman. Novos Estudos Cebrap, n.24, pp.166-178.

PHELAN, John.

(1979). El origen de la idea de Latinoamérica. Cuadernos de Cultura Latinoamericana. 31. México: CCyDEL/UNAM.

PRAD0, Maria Ligia; PELLEGRIN0, Gabriela. (2016). História da América Latina. São Paulo: Contexto.

QUIJADA, Mónica.

(1997). Latinos y anglosajones. El 98 en el fin de siglo sudamericano. Hispania: Revista española de Historia, v. LVII/2, n. 196, pp.589-609.

RETAMAR, Roberto Fernandez.

(1983). Introdução a José Martí. In: MARTÍ, José. Nossa América. São Paulo: Hucitec.

RETAMAR, Roberto Fernandez.

(1988) Caliban e outros ensaios. São Paulo: Busca Vida.

RICUPERO, Bernardo.

(2016). Ariel na América: viagens de uma ideia. Interseções, v.18, n.2, pp. 372-407.

RODÓ, José Enrique.

(1991). Ariel. Campinas: UNICAMP.

ROJAS MIX, Miguel.

(1997). Los cien nombres de América: eso que descubrió Colón. San José, Editorial de la Universidad de Costa Rica.
SCHWARTZMAN, Simon.

(1988). 0 espelho de Morse. Novos Estudos Cebrap, n.22, pp.185-192.

SCHWARTZMAN, Simon.

(1989). 0 gato de Cortázar. Novos Estudos Cebrap, n.25, pp.191-203.

VIANNA, Luiz Werneck.

(1991). Americanistas e iberistas: a polêmica de Oliveira Vianna com Tavares Bastos. Dados, v.34, n.2, pp.145-189.

VIANNA, Luiz Werneck.

(1997). A Revolução Passiva: Iberismo e Americanismo na Formação Brasileira. Rio de Janeiro: Revan.

WASSERMAN, Claudia.

(2004). Percursos intelectuais latinoamericanos: “Nuestra América” de José Martí, e "Ariel" de José Enrique Rodó - as condições de produção e o processo de repercussão do pensamento identitário. Diálogos, v.8, n.1, pp.51-66.

ZEA, Leopoldo.

(1976). El pensamiento latinoamericano. México: Editorial Ariel.

\section{Recebido em}

dezembro de 2018

\section{Aprovado em}

novembro de 2019 